\title{
A new method to calculate soil loss tolerance for sustainable soil productivity in farmland
}

\author{
Xingwu Duan ${ }^{1,2} \cdot$ Xiaoning Shi $^{1} \cdot$ Yanbo $\mathrm{Li}^{1,2} \cdot \mathrm{Li}^{1} \operatorname{Rong}^{1,2} \cdot$ Detai Fen $^{1}$
}

Accepted: 2 December 2016/Published online: 19 December 2016

(C) INRA and Springer-Verlag France 2016

\begin{abstract}
Soil loss tolerance (T) is a widely used concept for assessing potential risks of soil erosion and is a criterion for assessing the effectiveness of soil and water conservation projects. However, current approaches for calculating $\mathrm{T}$ values lack a strong scientific basis, and few practicable methods are available. Many questions remain regarding which parameters, such as planning periods and offset damages, should be included in calculating $\mathrm{T}$ values. Here, we developed a new method to calculate soil loss tolerance as a function of the soil productivity index (SPI) for farmland. To achieve sustainable soil productivity in farmland, erosion rates leading to SPI values lower than the lower boundary of soil productivity (SPI0) are not tolerable and must be controlled by soil conservation measures. We applied this method in the Red River Basin of China based on the investigation of typical soil profiles and crop yields. Our results show that the T values in the Red River Basin ranged from 0.91 to $10.24 \mathrm{t} \mathrm{ha}^{-1} \mathrm{a}^{-1}$. The SPI0 and the lowest limit of soil loss tolerance (T1) were 0.4 and $0.91 \mathrm{tha}^{-1} \mathrm{a}^{-1}$, respectively. Here, we demonstrate that, when determining $\mathrm{T}$ values in farmland, (1) the soil formation rate and offset damage should not be core items, (2) the "planning period" concept should be replaced by "sustainability", (3) the management objective of T should be the sustainability of the soil resource, and (4) the T values of farmland should be determined according to soil productivity. We provide a
\end{abstract}

Xingwu Duan

xwduan@ynu.edu.cn

1 Institute of International Rivers and Eco-security, Yunnan University, Kunming 60095, China

2 Yunnan Key Laboratory of International Rivers and Trans-boundary Eco-security, Yunnan University, Kunming 10095, China reasonable and feasible method to determine $\mathrm{T}$ for farmland, which will help maintain the sustainability of soil productivity.

Keywords Soil formation rates $\cdot$ Offset damage ·

Sustainability $\cdot$ Soil function $\cdot$ Soil productivity

\section{Introduction}

Erosion is defined as the detachment, movement, and deposition of soil or rock by water, wind, ice, or gravity (Soil Science Society of America 2008). As an important natural Earth surface process, erosion plays a key role in the development of landforms and landscapes. Among other effects, erosion lowers the land surface (denudation) as sediment moves from uplands to marine environments, thereby linking the terrestrial and aquatic systems (Renschler and Harbor 2002). Under natural conditions, soil erosion and weathering are usually balanced (Amundson et al. 2015). However, human activities, such as farming, fire, and grazing, usually increase the erosion rate and lead to so-called accelerated erosion (Beniston et al. 2015; Berendse et al. 2015; Simonneaux et al. 2015). Land use has been shown to amplify soil losses (Pacheco et al. 2014; Valle Junior et al. 2014). Accelerated erosion (erosion for short in this paper) can reduce soil nutrient contents, degrade soil structure, and reduce the effective rooting depth, thereby reducing soil productivity (Biggelaar et al. 2003; Tenberg et al. 2014; Valera et al. 2016). Erosion is estimated to reduce crop production by 192 million tons $(t)$ of cereals, 6 million $t$ of soybeans, 3 million $t$ of pulse, and 73 million $t$ of roots and tubers worldwide each year (Lal 2001). To protect soils from excessive erosion and soil productivity degradation, Hays et al. (1941) proposed the concept of soil loss tolerance (T). Wischmeier and Smith (1979) defined T as "the maximum level of soil erosion that will permit a high level of crop 
productivity to be sustained economically and indefinitely". Subsequently, many scholars have defined T in different contexts (Li et al. 2009; Bui et al. 2011; Liu et al. 2015), but the definition proposed by Wischmeier and Smith (1979) remains the most widely used (Schertz and Mark 2006).

As a criterion for controlling erosion rates, the determination of the $\mathrm{T}$ value is one of the most important aspects of soil and water conservation projects. Hays et al. (1941) quantified the $\mathrm{T}$ value of the Fayette silt loam, and they considered topsoil depth as the reference. Browning et al. (1947) identified soil productivity as the most important index for establishing $\mathrm{T}$ values and suggested $\mathrm{T}$ values between 4.50 and $13.50 \mathrm{t} \mathrm{ha}^{-1} \mathrm{a}^{-1}$ for 12 soils in the western USA. In 1956, the American Soil Conservation Service (SCS) organized a committee to discuss potential items in the determination of $\mathrm{T}$ values (soil depth, nutrient loss, maintenance of water control structures, control of sedimentation and gullies, yield reduction, water loss, and seeding loss). The committee set the upper limit on the $\mathrm{T}$ value to $11.2 \mathrm{tha}^{-1} \mathrm{a}^{-1}$ (Paschall et al. 1956). The SCS held six regional workshops from 1961 to 1962 to discuss the criteria for establishing $T$ values, which led to the establishment of $\mathrm{T}$ values for 12 soil orders in each region of the USA (Johnson 1987). Although the criteria have been modified, their basic structure remains in use today (Schertz and Mark 2006). Following these criteria, many countries, including China (Ministry of Water Resources of the People's Republic of China 1997), Russia (Shtomrel et al. 1998), other European countries (Verheijen et al. 2009), Brazil (Lombardi and Bertoni 1975), Australia (Bui et al. 2011), and India (Mandal and Sharda 2013), have formulated corresponding $\mathrm{T}$ values. Today, $\mathrm{T}$ values have become the basis for judging the potential risks of soil erosion and the evaluation criteria for soil and water conservation projects worldwide (Li et al. 2009).

Despite the importance of $\mathrm{T}$ for soil conservation, the current criteria for determining $\mathrm{T}$ values depend mainly on the expertise of the individuals involved. A consensus on which items should be considered and how to determine the $\mathrm{T}$ value is still lacking (Schertz 1983; McCormack et al. 1982; Johnson 1987; Cook 1982; Li et al. 2009; Duan et al. 2012). Soil thickness, soil formation rate, and the effect of soil erosion on soil productivity are regarded as the most important influencing factors ( $\mathrm{Li}$ et al. 2009; Bui et al. 2011). The three major quantitative methods used for estimating the $\mathrm{T}$ value are based on soil thickness, soil formation rate, or soil productivity. Some studies showed that soil productivity did not decline unless the soil loss rate surpassed the soil formation rate (Flach 1983). Based on this hypothesis, Alexander (1988a, b) developed a method to determine $\mathrm{T}$ based on the estimation of soil formation rates. However, two issues limit the application of this method. First, soil formation rates are quite different in parent materials and the A horizons, and it is very difficult to measure soil formation rates for different types of soils
(Johnson 1987; Hall et al. 1985; Hancock et al. 2015). Second, soil formation rates are slow, and soil erosion exceeds the rate of soil formation in almost all sloped crop lands, rendering T values impossible to estimate (Schertz 1983).

The method based on soil productivity was developed by Smith and Stamey (1965). The basic premise is that, to maintain the sustainability of soil resources, soil productivity (expressed by some measurable soil properties) should not be lower than a certain critical value within a given time frame. An ideal T equation was developed according to this definition and consisted of time, location, some measurable soil properties, and the soil formation rate. However, this equation did not specify how to assess soil productivity or what the critical value of soil productivity should be. Subsequently, Skidmore (1982) improved the method by introducing soil depth as a parameter. Parameters such as tolerant minimum soil depth, optimal soil depth, current soil depth, and upper and lower limits of soil loss tolerance were also included. However, the relationship between soil depth and soil productivity is complex, and an equivalent soil thickness between two soils does not mean that the soil productivities are equivalent (Duan et al. 2009). Furthermore, it is difficult to determine some of the model parameters, such as the tolerant minimum and optimal soil depth. As a result, very little progress has been made in the application of Skidmore's soil depth equation since it was proposed (Pretorius and Cooks 1989; Li et al. 2009).

In the meantime, debate has continued regarding whether offset damage should be included and how to formulate the planning period. From 1976 to 1977, the prevention of offset damage as a factor in determining the $\mathrm{T}$ value was discussed extensively by the SCS (McCormack et al. 1982). Wischmeier and Smith (1979) argued that it would be possible to establish a specific limit on the amounts of soil erosion to control water quality. Renschler and Harbor (2002) argued that the determination of $\mathrm{T}$ should include the offset damage related to soil erosion. Rittall and Swader (1979) suggested setting a separate $\mathrm{T}$ standard for water quality objectives. The SCS suggested setting a "soil delivery tolerance" for the purposes of preventing offset damage (Flach 1983). In regard to the planning period, Schertz (1983) suggested that a specific, set time interval of 500 or even 1000 years would be more practical for sustaining production than the use of terms such as "over a long period of time" when setting tolerances. Sparovek and Schnug (2001) reported that 50 to 100 years was reasonable for the determination of T values. Benson et al. (1989) proposed that a $5 \%$ reduction in soil productivity over 100 or 500 years was acceptable. Runge et al. (1986) used 100 years as the time period to calculate $\mathrm{T}$ values. To protect farmland, Morgan (1987) defined a "finite point" as the point at which yields fall below $75 \%$ of the maximum possible yield. Montgomery (2007) noted a reasonable historical pattern of 500- to several-thousand-year life spans for major civilizations around 
the world. Other studies have expressed soil loss tolerance using the concept of "soil life time" (Sparovek and Schnug 2001; Sparovek et al. 1997).

It is clear that new approaches are needed for the determination of $\mathrm{T}$ values based on extensive scientific evidence and practicability. We argue that the earlier challenges in establishing of $\mathrm{T}$ values resulted from a lack of clear managementoriented objectives and that such objectives need to be related to soil functions. Different types of soils provide different services to society (Amundson et al. 2015; Stavi et al. 2016; Francesconi et al. 2016). The most important role of farmland soils is soil productivity because these soils directly provide food (Sanchez 2002; Pimentel 2006; Mafongoya et al. 2016). Soils under natural forest and grasslands provide ecological services, such as climate regulation, biological control, and biotransformation of organic carbon; therefore, these roles need to be emphasized (Verheijen et al. 2009; Stavi et al. 2016). Providing clean water and energy is more important for soils in some special areas in natural reserves, headwaters, and areas with major mineral deposits. For these soils, the introduction and mitigation of pollution, sediment input, and water quality should be considered when setting $T$ values. Therefore, the objectives and the method of setting $\mathrm{T}$ need to be determined according to soil services and functions. In this paper, we propose a new framework to determine $T$ values for different types of soils. We propose a method to calculate $\mathrm{T}$ values for farmland based on the concept of sustainable soil productivity. Finally, we applied this method in the Red River Basin of China (Fig. 1) and discussed the relationship between soil formation rates, offset damage, planning time, and farmland $\mathrm{T}$ values.

\section{Materials and methods}

\subsection{Framework for determining regional soil loss tolerance}

As Mannering (1981) observed, scientists have proposed more questions than they have solved, resulting in confusion "regarding what are known and what are not known about the bases of T values". We propose that the problem is partly rooted in a lack of clear management objectives. Soil functions were seldom considered by previous studies when calculating $\mathrm{T}$ values. For different soil resources, the management objective for establishing $\mathrm{T}$ should be different. Based on the concept of soil functions, we propose a new framework for determining regional $\mathrm{T}$ values (Fig. 2). The framework includes three steps: (1) soils are divided into four categories based on societal services: farmland, forestland/grassland, mineral/industrial, and important natural reserves/headwaters; (2) influencing factors (for establishing $\mathrm{T}$ ) are identified for each category based on the soil function; and (3) a calculation method is established for each category of soil.

In forest and grasslands, ecological service-related factors, such as organic matter content, soil formation rates, erosion rates, and pollution offset, may be selected as variables influencing $T$. $T$ values in such areas can be determined based on the soil formation rate or the erosion rate. The $\mathrm{T}$ value standard in forest and grasslands should be higher than in farmland. Soils in major mineral and industrial areas, important natural reserves, and in headwaters may pose potential danger to the health and wellbeing of people. Therefore, determining the $\mathrm{T}$ values for those soils should consider pollution, water quality, and erosion rate, among other factors. The highest standard of $\mathrm{T}$ values would be preferred in such areas to better control the erosion modulus through soil and water conservation projects (both biological and engineering). From the perspective of a manager, it is relatively simple to set a single high $\mathrm{T}$ standard in forest/grasslands and major mineral and industrial areas. However, in farmland, soil productivity-related factors, including soil depth, soil fertility, control of gully formation, and water losses, are selected as variables influencing $\mathrm{T}$, and $\mathrm{T}$ values should be calculated with soil productivity-based methods. Furthermore, soil productivity may vary greatly with different types of soil, climate, and topographic condition (Duan et al. 2015). Consequently, determining the $\mathrm{T}$ values in farmland is the most complex and difficult. Due to the irreplaceable role of farmland in providing food for humans and the poor quality of the farmland $\mathrm{T}$ value calculation method currently available, this study focuses on the determination of a relatively liberal $\mathrm{T}$ value calculation method for farmland.

\subsection{Cropland soil loss tolerance based on sustainable soil productivity}

In the 1980s, following intensive studies of the long-term effects of soil erosion on soil productivity, scientists realized that the key question for determining $\mathrm{T}$ values was "how much soil loss is tolerable without damaging their productivity?" (Schertz 1983; Cook 1982). To address this question, Skidmore (1982) developed a mathematical equation for soil loss tolerance based on soil depth.

$T(x, y, t)=\left(T_{1}+T_{2}\right) / 2-\left(T_{2}-T_{1}\right) / 2 \cos \left(\pi\left(Z-Z_{1}\right) /\left(Z_{2}-Z_{1}\right)\right)(1)$

where $T(x, y, t)$ is the $T$ value at point $(x, y)$ at time $t$ (i.e., the present), $T_{1}$ is the lower limit of T, $T_{2}$ is the upper limit of $T, Z$ is the present soil depth, $Z_{1}$ is the minimum allowable soil depth, and $Z_{2}$ is the optimum soil depth. The soil loss tolerance function between the points $\left(T_{1}\right.$, 


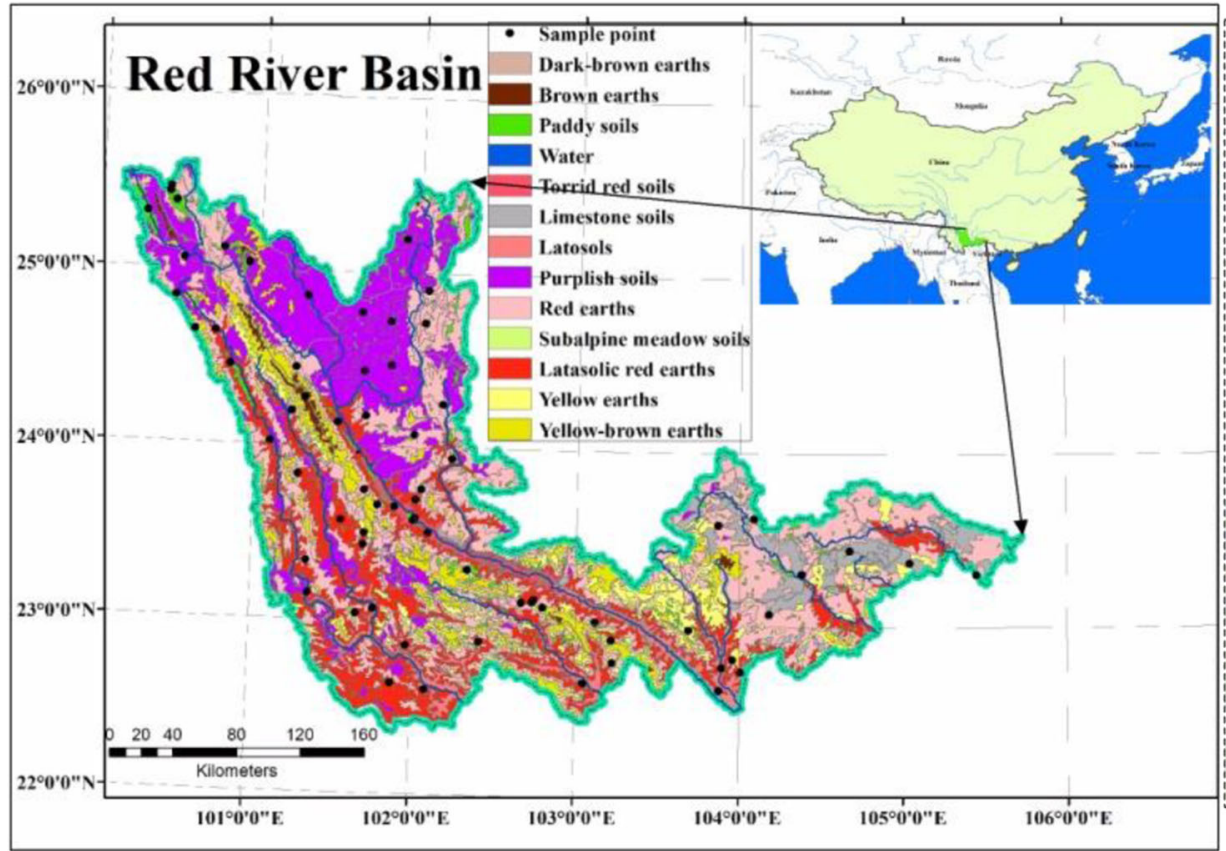

Steep slope cultivation in the basin

Fig. 1 Sketch of the Red River Basin, distribution of soil types, and sample points. The two pictures show steep slope cultivation and soil erosion in the Red River Basin

$\left.Z_{1}\right)$ and $\left(T_{2}, Z_{2}\right)$ is sinusoidal and dependent upon soil depth, and $\left(T_{2}-T_{1}\right) / 2$ is the amplitude. The period is represented by the cosine argument from $0^{\circ}$ to $180^{\circ}$ for values of $Z$ between $Z_{1}$ and $Z_{2}$. However, soil thickness cannot completely express the soil productivity level, as equivalent soil thicknesses do not mean identical soil productivities. Furthermore, it is very difficult to identify the equation parameters of "minimum allowable soil depth," which is critical for finding the answer to the question "how much soil productivity can be lost?" (Cook 1982).
We developed a new method for analyzing soil loss tolerance for farmland based on the following two perspectives. First, the main objective for setting soil loss tolerance in farmland is the protection of soil productivity; thus, soil productivity becomes the most important influencing factor for the establishment of T. Second, to maintain sustainable soil productivity, the soil productivity level should be higher than a threshold, which we defined as the lowest tolerable soil productivity. Under this definition, we can answer the question "how much erosion can be tolerated before unacceptable
Fig. 2 A simple sketch map of the framework for determining regional $\mathrm{T}$ values based on soil functions

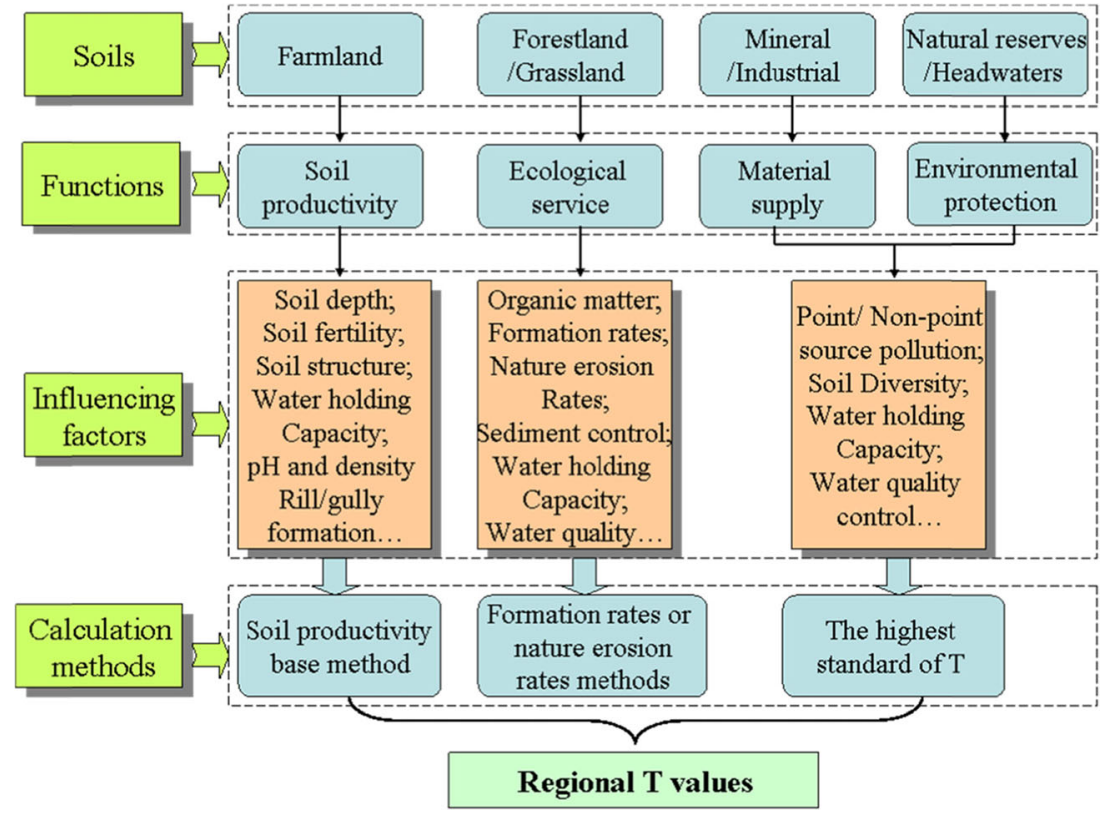


reductions in plant productivity are incurred" (Schertz 1983). Following Skidmore's equation, we replaced soil depth $(Z$ in
Eq. 1) with the soil productivity index (SPI). Then, the soil loss tolerance can be calculated with the following equation:

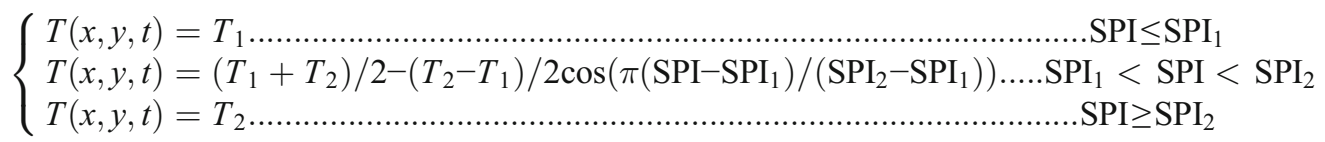

where $T(x, y, t)$ is the $\mathrm{T}$ value at point $(x, y), T_{1}$ is the lower limit of $\mathrm{T}, T_{2}$ is the upper limit of $\mathrm{T}, \mathrm{SPI}_{0}$ is the present soil productivity, $\mathrm{SPI}_{1}$ is the lowest tolerable soil productivity index, and $\mathrm{SPI}_{2}$ is the optimum soil productivity index.

$T_{1}$ is the lower limit of $\mathrm{T}$ in farmland when soil productivity in a specific location $(x, y)$ is reduced to the lowest tolerable value ( $\left.\mathrm{SPI}_{1}\right)$, and soil erosion rates should be no less than $T_{1}$. Determination of $T_{1}$ may include topsoil formation rates and the costs and feasibility of soil and water conservation under current economic and technical conditions. If controlling erosion rates under $T_{1}$ is impossible, the farmland in location $(x$, $y$ ) should be transformed into grassland or forestland to recover its productivity. $T_{2}$ is the upper limit of $\mathrm{T}$, when soil productivity in a specific location $(x, y)$ reaches the optimum level $\left(\mathrm{SPI}_{2}\right)$, and soil erosion rates should not exceed $T_{2}$. The determination of $T_{2}$ could be based on the upper standard of USDA-NRCS (1999) (11.2 $\left.\mathrm{t} \mathrm{ha}^{-1} \mathrm{a}^{-1}\right)$.

$\mathrm{SPI}_{0}$ is the present soil productivity index. It can be calculated using the soil productivity index model (PI) established by Pierce et al. (1983) and modified by Montgomery and Payton (1999) and Duan et al. (2009). The PI model has been widely used to assess soil productivity (Udawatta and Henderson 2003) and the long-term effects of soil erosion on soil productivity (Lobo et al. 2005). The PI value, ranging from 0 to 1, represents the relative soil productivity determined based on soil properties in soil profiles. Sufficiency values were defined to quantify the effects of soil properties on soil productivity, and the SPI value is calculated by summing the product of the sufficiency values for each soil layer to a depth of $100 \mathrm{~cm}$. The following equation is the PI model modified by Duan et al. (2009).

$\mathrm{PI}=\sum_{i=1}^{n}\left(A_{i} \times D_{i} \times O_{i} \times \mathrm{CL}_{i} \times \mathrm{WF}_{i}\right)$

where $i$ is the number of the soil layer, and $n$ is the total number of soil layers within the rooting depth. $\mathrm{A}_{i}$ is the sufficiency of available soil water capacity, $D_{i}$ is the sufficiency of $\mathrm{pH}, O_{i}$ is the sufficiency of organic matter content, $\mathrm{CL}_{i}$ is the sufficiency of clay (particle size $<0.002 \mathrm{~mm}$ ) content, and $\mathrm{WF}_{i}$ is the weight of the $i$ th layer, which determines the use of soil moisture by crops under ideal conditions. However, this model does not provide a precise measurement of productivity potential for various environmental conditions (Gantzer and McCarty 1987;
Duan et al. 2009), which would require modifications according to the correlations between soil properties and crop yields and among different soil properties in the study area.

$\mathrm{SPI}_{1}$ is the lowest tolerable soil productivity index. Three steps are necessary to determine $\mathrm{SPI}_{1}$ : (1) establishment of a mathematical equation for the relationship between SPI and crop yield, (2) verification of the economic lowest tolerable crop yield per hectare (input is higher than output), and (3) calculation of SPI ${ }_{1}$ based on the lowest tolerable crop yield and the mathematical equation for the relationship between SPI and crop yield. $\mathrm{SPI}_{2}$ is the optimum soil productivity index, and according to the SPI model, $\mathrm{SPI}_{2}$ should be 1 .

\subsection{The case study}

\subsubsection{Site description}

The increasing human population and demands on food production, combined with limited land resources, has led to the encroachment of cultivation onto increasingly steep slopes in southern China, resulting in severe soil erosion (Barton et al. 2004). Cropland established on slopes is essential to regional food production and economic development. These conditions necessitate the establishment of a reasonable $\mathrm{T}$ value for sustainable development in the region. We selected a section of the Red River Basin in southern China as a study area (Fig. 1). The Red River Basin is located between $22^{\circ} 27^{\prime} 7$ and $25^{\circ} 32^{\prime} \mathrm{N}$ and $100^{\circ} 06^{\prime}$ and $105^{\circ} 40^{\prime} \mathrm{E}$ and covers an area of approximately $7.4 \times 10^{4} \mathrm{~km}^{2}$. It borders the Ailao Range and Mekong River to the west, Vietnam and Laos to the south, Guizhou Province of China and the Pearl River to the east, and the Jinsha River to the north. The Red River (called Yuanjiang in Chinese) flows across the red soil plateau (the Yunnan Plateau). The region features a mean elevation above sea level of $1529 \mathrm{~m}$, ranging from $<100 \mathrm{~m}$ in the southeastern hilly region to $>3000 \mathrm{~m}$ in the Ailao Mountains in the west. The climate is typically subtropical monsoonal, with influences from the southwestern, southeastern, and northeastern monsoons and extratropical westerlies (Cheng et al. 2009). Rainfall is abundant but unevenly distributed spatiotemporally. Annual rainfall in most parts of the basin is $1100 \mathrm{~mm}$. Precipitation occurs mainly in May to October and is 
concentrated in June to August (Miao and Xiao 1995). According to a land use survey, of the $1.3 \times 10^{6}$ ha of cropland in the basin, more than $82 \%$ has a slope $>6^{\circ}$, $61 \%$ has a slope $>15^{\circ}$, and $29 \%$ has a slope $>25^{\circ}$. Most of the cropland is currently cultivated with corn, wheat, sugarcane, and tobacco. The most widely distributed soils are Red earths, Latosols, Latosolic red earths, Purplish soils, and Paddy soils according to the Genetic Soil Classification of China (GSCC) (National Soil Survey Office of Yunnan Province 1996), which correspond to Haplic Alisols, Calcaric Regosols, and Fluvisols according to the FAO soil classification (FAO/UNESCO 1998). Abundant precipitation coupled with widespread sloping farmland has resulted in severe soil erosion and large amounts of river sediment (Quynh et al. 2005).

\subsubsection{Investigation of typical soil profiles and crop yields}

To assess soil productivity in the Red River Basin, we conducted a field survey of species from June to September 2012. Based on the Second National Soil Survey results (The National Soil Survey Office 1995), we selected 65 soil species in 10 soil groups and sampled a typical soil profile for each soil species. We used GPS and topographic maps to locate soil profiles for surveying. At each site, we recorded location, topography, slope, land use types, and vegetation types. We sampled soil profiles following the soil survey standards as outlined by Liu (1996) and Wang and Zhang (1983) and used soil color charts to determine the soil genetic horizons (RGCRG 1995). For each layer, we collected one mixed sample ( $2 \mathrm{~kg}$ of uniformly mixed soil sampled from the top to the bottom of the genetic horizon) and three undisturbed samples with a soil corer (55 $\mathrm{mm}$ in diameter, $50 \mathrm{~mm}$ height, sampled in the middle of the genetic horizon). We used the undisturbed samples to analyze bulk density (BD) and the disturbed soil samples to analyze other soil physicochemical properties (Dane and Topp 2002; Liu 1996). We collected cultivation method and crop data, including crop type, management model, and crop yields, from the land block in which the soil profile was located.

To modify the SPI model, we monitored the degree of soil erosion, soil physicochemical properties, and crop yields in the Laozhai watershed (Fig. 1). The Laozhai watershed is an area of $0.57 \mathrm{~km}^{2}$, of which $85 \%$ is farmland. The degree of soil erosion in the Laozhai watershed was assessed by determining the composition of soil genetic layers according to the National Standards for Classification and Gradation of Soil Erosion (Ministry of Water Resources of the People's Republic of China 1997). Forty-four sites were selected for monitoring of the effects of soil erosion on soil productivity. The crop rotation used in the study area is continuous corn (Zea mays L.), which is sown in June and harvested in October. At full maturity, corn yields were sampled in a rectangular harvest plot $(1.43 \mathrm{~m} \times 0.7 \mathrm{~m})$ centered at each point during the harvest period from 2012 to 2013 . Biomass was harvested at ground level and was immediately oven-dried at $80{ }^{\circ} \mathrm{C}$ to determine seed yields and the aboveground biomass for each plot. Soil samples were collected from each profile in each monitoring site according to soil survey standards (Liu 1996).

Primary physicochemical properties, particle size distribution, organic matter content $(\mathrm{OM}), \mathrm{pH}, \mathrm{BD}$, available water capacity (AWC), alkali-hydrolyzable nitrogen (EN), Olsen-extractable phosphorus (EP), and available potassium content (EK) were tested for all soil samples based on the National Soil Analysis Standards (Liu 1996). The particle size distribution (sand $=0.020-2.000 \mathrm{~mm}$, silt $=0.002-0.020 \mathrm{~mm}$, and clay $=<0.002 \mathrm{~mm}$ ) was measured using the pipette method after $\mathrm{H}_{2} \mathrm{O}_{2}$ treatment to remove organic matter. The $\mathrm{OM}$ was measured using a combustion method after passing the soil samples through a $0.015-\mathrm{cm}$ sieve. The BD was measured using the cutting ring method, the AWC was measured by pressure membrane method, and $\mathrm{pH}$ was measured via the potential method (the soil water ratio was 2.5:1). EN was determined using the alkali N-proliferation method, EP was extracted using the Olsen method, and EK was extracted with $\mathrm{NH}_{4} \mathrm{OAc}$.

\section{Results and discussion}

\subsection{Modification and validation of soil productivity model}

The key step in modifying the PI model is the selection of model parameters that not only represent physicochemical properties in the research region but also have major effects on crop growth and are relatively independent of each other (Duan et al. 2009). Correlation analysis between soil physicochemical properties and corn yields in the Laozhai watershed showed that there were significant positive correlations between corn yields and $\mathrm{pH}$ and between OM and EK. The absolute values of the correlation coefficients exhibited an order of $\mathrm{EK}>\mathrm{pH}>\mathrm{OM}>\mathrm{EN}=$ sand $>$ clay $>$ AWC $>$ silt $>$ BD $>$ EP. The redundancy analysis (RDA) also showed that EK was the dominant factor controlling crop yields in the study area. The results of the R-cluster analysis of 10 soil physicochemical properties showed that, between the rescaled cluster distance of $12-16$, these properties could be divided into 5 classes (Fig. 3): $\mathrm{BD}$ and $\mathrm{pH}$ in the first class, sand and $\mathrm{AWC}$ in the second, EK and EP in the third, OM and $\mathrm{EN}$ in the fourth, and clay and silt in the fifth. 


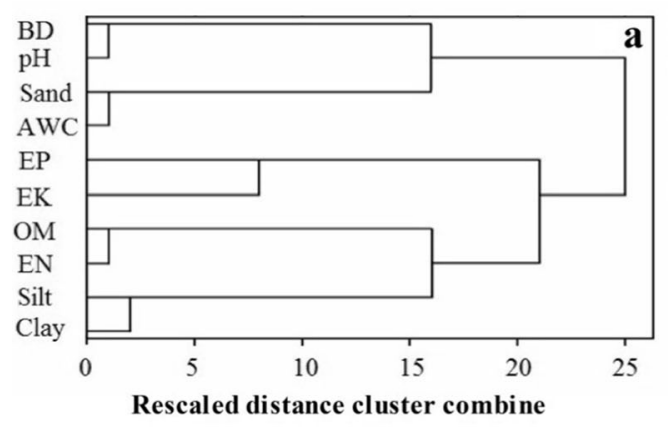

Fig. 3 a The dendrogram of soil physicochemical parameters using centroid clustering method. $B D$ is soil bulk density, $A W C$ is available water capacity, $A K$ is available potassium, $E N$ is alkali-hydrolyzable nitrogen, $E P$ is Olsen-extractable phosphorus, $O M$ is soil organic matter. b Regression analyses between corn yield and productivity

Based on the correlation between soil physicochemical properties and crop yield, we selected one property from each class to be a model parameter, as follows: EK, OM, AWC, clay content, and $\mathrm{pH}$. The following modified SPI model was constructed:

$\mathrm{SPI}=\sum_{i=1}^{n}\left(A_{i} \times D_{i} \times O_{i} \times K_{i} \times \mathrm{CL}_{i} \times \mathrm{WF}_{i}\right)$

where SPI is the soil productivity index, $K i$ is the sufficiency value of EK in the $i$ th soil layer, and the other terms have the same meaning as in Formula (1).

The impact of EK on soil productivity was generally represented by "the more the better" type of standard scoring functions (Wan et al. 2001). Within a certain range, the contribution of EK to soil productivity increased with increasing EK content; however, above a certain critical point, EK did not affect soil productivity. For most crops, the critical value of EK is $170 \mathrm{mg} / \mathrm{kg}$ ( $\mathrm{Lu} \mathrm{1998).} \mathrm{The} \mathrm{sufficiency} \mathrm{value} \mathrm{of} \mathrm{EK}$ can be calculated with the following equation:

$K_{i}=\left\{\begin{array}{l}\frac{\mathrm{AK}_{i}}{170 \ldots \ldots \ldots \ldots \ldots \ldots . . .} 0 \leq \mathrm{AK}_{i}<170 \\ 1 \ldots \ldots \ldots \ldots \ldots \ldots \ldots . . .170 \leq \mathrm{AK}_{i}\end{array}\right.$

where $K i$ stands for the sufficiency value of $E K$ in the $i$ th soil layer, and $\mathrm{EK} i$ stands for the $\mathrm{EK}$ content in the $i$ th layer (mg kg ${ }^{-1}$ ). The sufficiency values of $A_{i}, D_{i}, O_{i}, \mathrm{CL}_{i}$, and $\mathrm{WF}_{i}$ were similar to those reported by Duan et al. (2009).

Regression of the SPI and original PI values with respect to yield showed that both productivity indices were significantly correlated with maize yield but that the SPI was more strongly correlated than the original PI (Fig. 3). The determination coefficient of regression was 0.1829 for PI and yield and 0.6353 for SPI and yield, indicating that $63.53 \%$ of crop yield can be explained by the SPI and that the remaining $36.47 \%$ can be attributed to other factors, such as climate and farming
Corn yield $\left(t \cdot h^{-1}\right)$

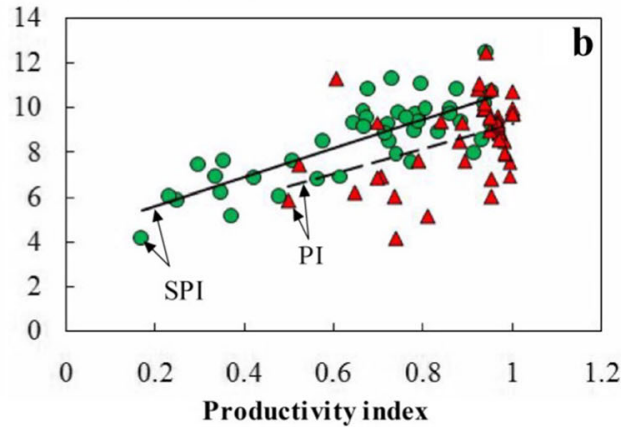

indices calculated by the two models. The regression equations for the SPI and PI models are $Y$ (corn yield $)=6.4789 \mathrm{SPI}+4.2934, R^{2}=0.6353$, $P<0.001$ and $Y$ (corn yield $)=5.6252 \mathrm{PI}+3.646, R^{2}=0.1829, P=0.004$, respectively. $S P I$ is the modified soil productivity index model, and $P I$ is original productivity index model

management. Therefore, the SPI was more suitable than the PI for assessing soil productivity in the research area. The regression equation to predict corn yield in the research region was as follows:

$Y=6.4789 \times$ SPI +4.2934

where $Y$ is the corn yield $\left(\mathrm{t} \mathrm{ha}^{-1}\right)$.

In this study, corn was used as the measure of yield to assess the accuracy of the SPI model. The relationships between soil productivity indexes and corn yield have been discussed by numerous researchers (Gantzer and McCarty 1987; Myers et al. 2000). Furthermore, as a simple and mature soil productivity evaluation model, the PI has been used to predict some other agronomic crops, such as soybean (Rijsberman and Wolman 1985; Yang et al. 2003), wheat (Wilson et al. 1991; Thompson et al. 1992), and sorghum (Rijsberman and Wolman 1985; Mulengera and Payton 1999), around the world. Almost all of those studies found a good relationship between soil productivity indexes and crop yields, where a high soil productivity index value corresponds to high crop yields in all crops.

\subsection{Calculation of the T value}

Based on the modified SPI model, we can determine the parameters in Eq. (2). In this study, the upper limit of $\mathrm{T}\left(T_{2}\right)$ refers to the upper standard of USDA-NRCS $\left(11.2 \mathrm{tha}^{-1} \mathrm{a}^{-1}\right)$, and the $\mathrm{SPI}_{0}$ is calculated using the modified SPI model (4). The optimum soil productivity index of $\mathrm{SPI}_{2}$ is 1 . According to the theory of "sustainable soil productivity," two parameters were determined: $\mathrm{SPI}_{1}$ and $T_{1}$. According to our investigation of the local corn planting cost (seed, fertilizer, pesticide, and labor inputs) and the corn market price, farming becomes unprofitable if the corn yield is lower than $7 \mathrm{t} \mathrm{ha}^{-1} \mathrm{a}^{-1}$. Thus, the lowest tolerable soil productivity index of SPI1 was set as 0.4 based on Eq. 6 and the above investment. 
Barton et al. (2004) investigated the effectiveness of five treatments (conventional tillage, no-tillage, straw mulch, polythene mulch, and intercropping) in this study area, and the results indicated that the best treatment was straw mulch because it controlled soil erosion rates at $0.91 \mathrm{t} \mathrm{ha}^{-1} \mathrm{a}^{-1}$. This erosion value is lower than the topsoil formation rates (Johnson 1987; Duan et al. 2002). We then used $0.91 \mathrm{t} \mathrm{ha}^{-1} \mathrm{a}^{-1}$ to set $T_{1}$, which meant that when the soil productivity in a specific location $(x, y)$ decreased to the lowest tolerable value $\left(\mathrm{SPI}_{1}\right)$, the soil erosion rates were not high than $T_{1}$. Soil and water conservation projects can control erosion rates in farmland on slopes under $T_{1}$ in current economic and technical conditions. Combined with topsoil formation and soil amendment measures, soil productivity can be maintained under $T_{1}$. With this, we modified Eq. (2) to Eq. (7) to specifically calculate the $T$ values of different types of soils in the Red River Basin.

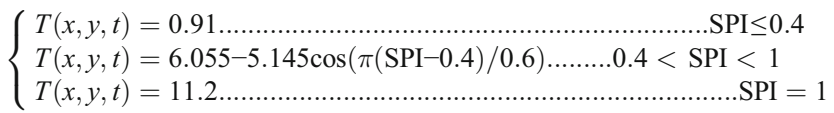

The $\mathrm{T}$ values for the 65 soil species ranged from 0.91 to $10.24 \mathrm{tha}^{-1} \mathrm{a}^{-1}$, with an average of $2.57 \mathrm{t} \mathrm{ha}^{-1} \mathrm{a}^{-1}$, which was $49 \%$ lower than the current national $\mathrm{T}$ standard in this region. The $\mathrm{T}$ values in the study area had the following order: Yellow-brown earths $<$ Purplish soils $<$ Subalpine meadow soils $<$ Latosols $<$ Limestone soils $<$ Red earths $<$ Latosolic red earths $<$ Paddy soils $<$ Yellow earths. Yellow-brown earths and Purplish soils had the lowest $\mathrm{T}$ values because these soils were mainly distributed in back slope areas in valleys, where soil erosion was severe (Duan et al. 2015). As a result, soil productivity was low and affected T accordingly (Fig. 4). Approximately $46 \%$ of the soil groups had lower soil productivity than the lowest tolerable soil productivity index. Therefore, the highest standard of soil and water conservation measures (no-tillage and straw mulch for example) should be used to control the soil erosion rates. Otherwise, these slopes could be converted to grass or forest lands in an effort to recover soil productivity. Furthermore, significant variability in $\mathrm{T}$ values was observed even among soils of the same type (Fig. 4). Therefore, setting a uniform standard for farmland $\mathrm{T}$ values at regional scales does not lead to sustainability, and this current practice in China (Ministry of Water Resources of the People's Republic of China 1997) needs to be revised.

\subsection{Soil formation rates and soil loss tolerance in farmland}

The soil formation rate has long been considered one of the most important factors in the determination of the $T$ value (Johnson 1987; Alexander 1988a, 1988b). However, we hold that it is unreasonable to use the T value standard based on soil formation rates in most farmland. One reason is that quantification of soil formation rates is challenging. Many environmental factors affect the rates of soil formation, and determining the influence of each factor is difficult (Hancock et al. 2015). Current scientific knowledge on soil formation processes is insufficient to support mechanistic models of soil formation in estimating soil loss tolerance (Verheijen et al. 2009). Furthermore, the pedogenetic processes of soil formation and weathering of parent material are very slow (Schertz 1983). Scientists suggest that soils form at a rate of $25.4 \mathrm{~mm}$ over 300 to 1000 years $\left(0.08-0.02 \mathrm{~mm} \mathrm{a}^{-1}\right)$ under natural conditions and at the rate of $25.4 \mathrm{~mm}$ over 100 years (0.02 $\mathrm{mm} \mathrm{a}^{-1}$ ) under farming conditions (Johnson 1987; Schertz 1983). Doran (1996) observed that it took 100 to 400 years on average to develop $1 \mathrm{~cm}$ of topsoil. Kendall and Pimentel (1994) indicated that it took hundreds to thousands of years to form a few centimeters of topsoil under normal agricultural conditions. Based on a literature review, Smith and Stamey (1965) found that weathering rates varied according to time, material properties, and depth of regolith, and they estimated the overall average to be approximately $0.5 \mathrm{t} \mathrm{ha}^{-1} \mathrm{a}^{-1}\left(0.05 \mathrm{~mm} \mathrm{a}^{-1}\right)$ in the central USA. McCormack et al. (1982) estimated the renewal rate to be $1.2 \mathrm{t} \mathrm{ha}^{-1} \mathrm{a}^{-1}\left(0.12 \mathrm{~mm} \mathrm{a}^{-1}\right)$ for unconsolidated parent materials and a much lower value for consolidated materials. Verheijen et al. (2009) estimated that the soil weathering rates under current conditions in Europe range from 0.3 to $1.2 \mathrm{t} \mathrm{ha}^{-1} \mathrm{a}^{-1}$ (0.03 to $\left.0.12 \mathrm{~mm} \mathrm{a}^{-1}\right)$. Finally, it is particularly important to note that soil erosion rates in farmland are far greater than soil formation rates (Verheijen et al. 2009; Bazzoffi 2009). Globally, soil erosion has been estimated to be 0.08 to $2.98 \mathrm{~mm} \mathrm{a}^{-1}$ for bare fallow fields, 0.02 to $0.55 \mathrm{~mm} \mathrm{a}^{-1}$ for plowed maize treatments, and 0.003 to $0.16 \mathrm{~mm} \mathrm{a}^{-1}$ for no-till maize treatments (Lal 2001). Using ${ }^{137} \mathrm{Cs}$ analysis, Van Oost et al. (2007) estimated that the global erosion rates ranged from 0.4 to $2.3 \mathrm{~mm} \mathrm{a}^{-1}$. Data compiled from 1673 measurements from 201 studies from a wide range of environments and geological settings showed that soil erosion rates under conventional agricultural practices almost uniformly exceeded $0.1 \mathrm{~mm} \mathrm{a}^{-1}$, with median and mean values $>1 \mathrm{~mm} \mathrm{a}^{-1}$ (Montgomery 2007). Worldwide, soil erosion rates in farmland were estimated to range from 6.33 to $18.37 \mathrm{t} \mathrm{ha}^{-1} \mathrm{a}^{-1}$ (0.6 to $1.8 \mathrm{~mm} \mathrm{a}^{-1}$ ) (Guo et al. 2015). Topsoil itself is currently being lost 16 to 300 times faster than it forms, depending on the region (Barrow 1994). The erosion rates of conventionally plowed agricultural fields are 1-2 orders of magnitude greater on average than the rates of soil production, erosion under native vegetation, and long-term geological erosion (Montgomery 2007).

In our new method, soil productivity is considered to be the key factor for the establishment of $\mathrm{T}$ in farmland. To sustainably use soil resources, the soil productivity level should be higher than the SPI1 value. High-productivity soils yield high 


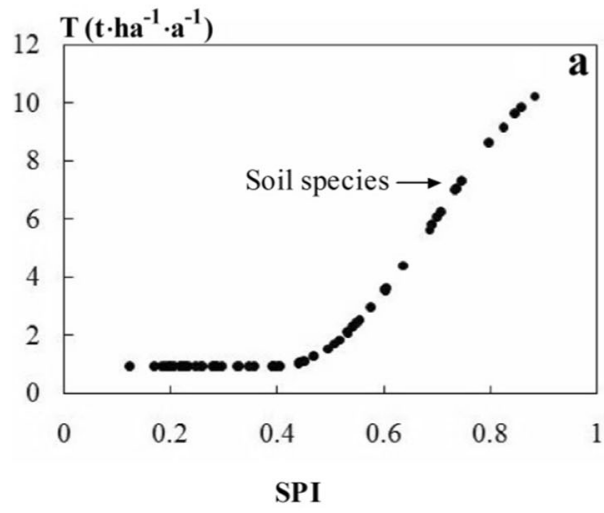

Fig. 4 a The relationship between soil productivity index and soil loss tolerance. b Soil loss tolerance values for different types of soils in the Red River region. $S P I$ is soil productivity index, $T$ is soil loss tolerance, $Y B E$ is Yellow-brown earths, TRS is Torrid red soils, $P S$ is Purplish soils,

$\mathrm{T}$ values. Soil formation rates can be an auxiliary reference factor for the $\mathrm{T}$ values of forest/grasslands and major mineral or industrial areas.

\subsection{Offset damage for soil loss tolerance in farmland}

Preventing offset damage associated with soil erosion is one of the most important objectives in soil and water conservation (Edwards 1962; Young 1980; Renard et al. 1997). However, consensus is lacking on whether the offset damage associated with soil erosion should be considered in the determination of T values (Renard et al. 1997; Schertz and Mark 2006). In our method, we suggest that the offset effect of soil erosion should not be considered a major factor in determining $\mathrm{T}$ values in farmland because the relationship between soil erosion rates and water quality is complex. Soil material eroded from farmland may be deposited in a variety of places before it reaches a watercourse, and the sediment discharge and the amount of deposition in sensitive areas depend on many factors, including the distance, transport conditions, sediment transport characteristics, and sediment composition (Schertz and Mark 2006). Sediments deposited near farmland do not directly affect water quality. Furthermore, nonpoint source pollution, which has a significant impact on water quality (Ongley et al. 2010), has little relevance to soil erosion rates (Braskerud 2002a, b). The main influencing factors for nonpoint source pollution include the geochemical composition, amounts and types of fertilizer and pesticides, agricultural management strategies, and the relative location of the farmland Basnyat et al. (2000); Zhang et al. 2004). Soil erosion is the driving force, but high soil erosion rates do not necessarily mean high nonpoint source pollution. However, offset damage should be an important factor for the $\mathrm{T}$ values of major mineral or industrial areas.

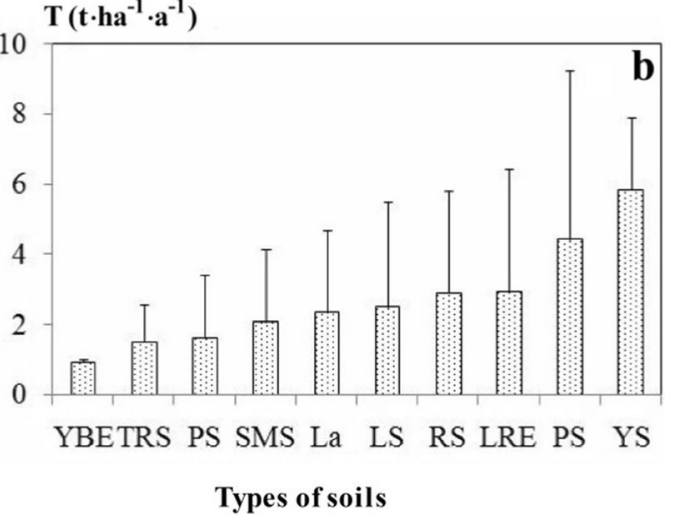

SMS is Subalpine meadow soils, $L a$ is Latosols, $L S$ is Limestone soils, $R S$ is Red earths, LRE is Latosolic red earths, $P S$ is Paddy soils, and $Y S$ is Yellow earths

\subsection{The planning period and soil loss tolerance in farmland}

One of the advantages of our method is that we do not have to consider the planning period. Incorporating the planning period into the determination of soil tolerance is complicated (Schertz 1983; Stocking 1984; Hall et al. 1985). The formation of topsoil is a very slow process, and topsoil can be considered a nonrenewable and irreplaceable resource for human use (Doran 2002). Human activities contribute to soil erosion processes in farmland, where soil loss generally exceeds formation. Therefore, soil resource depletion has become a challenge (Lal 2001; Biggelaar et al. 2003), which is why scientists want to include the planning period in the determination of the T value (Nowak et al. 1985; Kuznetsov and Abdulkhanova 2013). In fact, soil resources are replaceable, they coexist with humans, and humans will need soil resources as long as they occupy the Earth. Therefore, the concept of a "planning period" for soil resources is unacceptable for humans. In farmland, technological advances, such as rational fertilization (Edmeades 2003; Keesstra et al. 2016), improved cultivation methods (Wilhelm et al. 2004), biological measures (Whiffin et al. 2007), and engineering measures (Teasdale et al. 2007), among others, can improve degraded soils by increasing soil productivity. Furthermore, reasonable soil and water conservation measures (biological, engineering, and tillage) can control farmland soil erosion rates (Schwab et al. 1993; Keesstra et al. 2016).

In our method, the objective of determining $T$ values is the sustainable use of soil resources, and the farmland $\mathrm{T}$ value can be determined according to soil productivity. High $\mathrm{T}$ values are given to high-productivity soils, and low $\mathrm{T}$ values are given to low-productivity soils (Fig. 4). The T value of a specific type of soil (defined by location and soil group) is not static and can be updated following a periodic study ( 5 years for example) of the soil resource. In this way, the $\mathrm{T}$ 


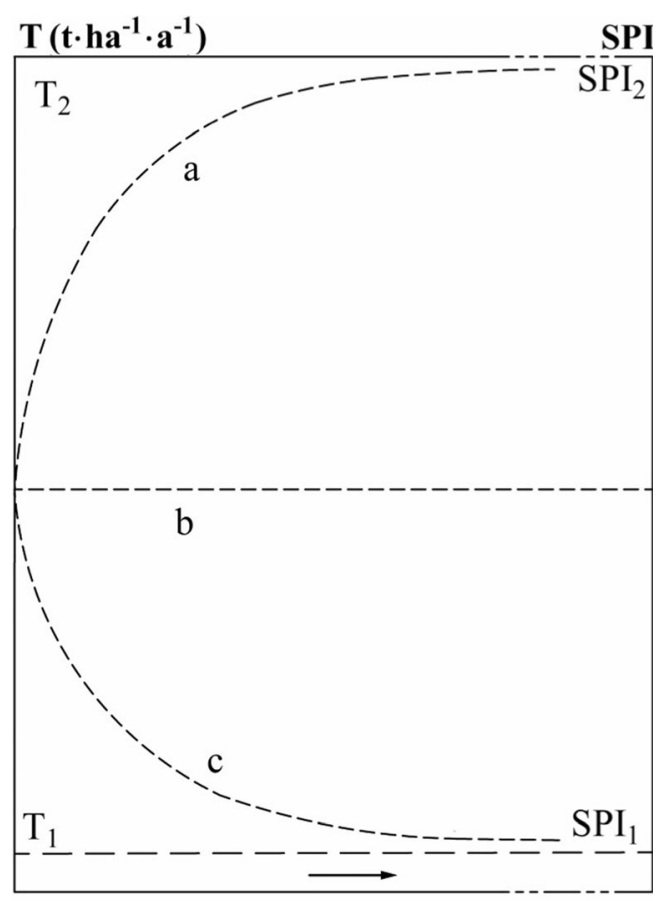

Time

Fig. 5 Graphical representation of the relationships among soil loss tolerance, soil productivity index, and time. $T$ is soil loss tolerance. $T_{2}$ and $T_{1}$ are the upper and lower limits of soil loss tolerance, respectively. $S P I$ is soil productivity index. $\mathrm{SPI}_{2}$ is the highest soil productivity (no limit on crop growth). $\mathrm{SPI}_{1}$ is the lowest tolerable soil productivity (to maintain sustainability, the soil productivity level should be higher than this threshold). Under effective (i.e., sustainable) management, the productivity and soil loss tolerance of soil "a" increase with time. Under poor management and accelerated erosion, the productivity and soil loss tolerance of soil "c" decrease with time. No significant change in productivity or soil loss tolerance value occurs for soil "b"

value could change according to soil productivity, and the T values of soils may increase under effective management or decrease under poor management (Fig. 5).

\section{Conclusions}

In this paper, we analyzed the relationship between soil function and soil loss tolerance and developed a new method to calculate $\mathrm{T}$ values to achieve sustainable soil productivity in farmland. We discussed factors that influence the rate of soil formation, offset damage, and the planning period on the determination of $\mathrm{T}$ values for farmland. Our findings led to the following conclusions.

1. Different types of soils perform different functions for humans. Therefore, soil functions should be considered when selecting control factors and devising calculation methods for T. For example, the most important role of farmland soil is soil productivity, while that of forest and grasslands is providing ecological services. With this in mind, we proposed a framework to determine $\mathrm{T}$ values based on soil functions.

2. In farmland, soil loss tolerance should be calculated as a function of the soil productivity index. In the case study area of the Red River watershed, the lowest tolerable soil productivity index value was 0.4 , and the lowest limit of soil loss tolerance was $0.91 \mathrm{tha}^{-1} \mathrm{a}^{-1}$. The $\mathrm{T}$ values of the 65 soil types ranged from 0.91 to $10.24 \mathrm{tha}^{-1} \mathrm{a}^{-1}$. Large variability in $\mathrm{T}$ values was observed even among soils of the same type, indicating that using a uniform $\mathrm{T}$ standard in farmland at the regional scale is not accurate and will not help in efforts to maintain sustainability.

3. The measurement of soil formation rates is inherently difficult, and the soil erosion rates in farmland exceed the soil formation rates. As a result, applying the same T value standard based on the soil formation rate to most farmland is not appropriate.

4. The relationship between soil erosion rate and water quality is complex and poorly understood. Soil material eroded from farmland may be deposited before it reaches a watercourse. Furthermore, nonpoint source pollution is mainly influenced by agricultural management and the geochemical background. As a result, the offset effect of soil erosion should not be considered a major factor when determining $\mathrm{T}$ values for farmland.

5. The concept of the "planning period" should be replaced with the concept of "sustainability," and the objective of determining the $\mathrm{T}$ value should be the sustainability of the soil resource. Therefore, the $\mathrm{T}$ values of farmland should be determined according to the soil productivity.

Acknowledgements This work has been supported by the National Natural Science Foundation Project of China (Grant numbers 41561063, 41101267, and 41401614), National Science and Technology Support Program (2013BAB06B03), and Department of Water Resources of Yunnan Province: Water Science and Technology Project.

\section{References}

Alexander EB (1988a) Rates of soil formation: implications for soil tolerance. J Soil Sci 145(1):37-45

Alexander EB (1988b) Strategies for determining soil-loss tolerance. Environ Manag 12(6):791-796. doi:10.1007/BF01867605

Amundson R, Berhe AA, Hopmans JW, Olson C, Sztein AE, Sparks DL (2015) Soil and human security in the 21 st century. Science 348(6235):1261071. doi:10.1126/science. 1261071

Barrow C (1994) Land degradation. Cambridge University Press, London Barton AP, Fullen MA, Mitchell DJ, Hocking TJ, Liu L, Bo Z, Zheng Y, Xia $Z$ (2004) Effects of soil conservation measures on erosion rates and crop productivity on subtropical Ultisols in Yunnan Province, China. Agric Ecosyst Environ 104(2004):343-357. doi:10.1016/j.agee.2004.01.034

Basnyat P, Teeter LD, Lockaby BG, Flynn KM (2000) The use of remote sensing and GIS in watershed level analyses of non-point source pollution problems. Forest Ecol Manag 128(1):65-73. doi:10.1016/S03781127(99)00273-X 
Bazzoffi P (2009) Soil erosion tolerance and water runoff control: minimum environmental standards. Reg Environ Chang 9(3):169-179. doi:10.1007/s10113-008-0046-8

Beniston JW, Shipitalo MJ, Lal R, Dayton EA, Hopins DW, Jones F, Dungait JAJ (2015) Carbon and macronutrient losses during accelerated erosion under different tillage and residue management. Eur J Soil Sci 66(1):218-225. doi:10.1111/ejss.12205

Benson VW, Rice OW, Dyke PT, Williams JR, Jones CA (1989) Conservation impacts on crop productivity for the life of a soil. J Soil Water Conserv 44(6):600-604

Berendse F, van Ruijven J, Jongejans E, Keesstra S (2015) Loss of plant species diversity reduces soil erosion resistance. Ecosystems 18(5): 881-888. doi:10.1007/s10021-015-9869-6

Biggelaar CD, Lal R, Wiebe K, Breneman V (2003) The global impact of soil erosion on productivity: I: absolute and relativity erosioninduced yield losses. Adv Agro 81:1-48. doi:10.1016/S0065-2113 (03)81001-5

Braskerud BC (2002a) Factors affecting phosphorus retention in small constructed wetlands treating agricultural non-point source pollution. Ecol Eng 19(1):41-61. doi:10.1016/S0925-8574(02)00014-9

Braskerud BC (2002b) Factors affecting nitrogen retention in small constructed wetlands treating agricultural non-point source pollution. Ecol Eng 18(3):351-370. doi:10.1016/S0925-8574(01)00099-4

Browning GM, Parish CL, Glass J (1947) A method for determining the use and limitations of rotations and conservation practices in the control of erosion in Iowa. Agron 39(4):65-73

Bui EN, Hancock G, Wilkinson SN (2011) ‘Tolerable' hillslope soil erosion rates in Australia: linking science and policy. Agric Ecosyst Environ 144(1):136-149. doi:10.1016/j.agee.2011.07.022

Cheng JG, Wang XF, Fan LZ, Yang XP, Yang P (2009) Variations of Yunnan climatic zones in recent 50 years. Pro Geo 28(1):18-24 (in Chinese)

Cook K (1982) Soil loss: a question of values. J Soil Water Conserv 37(2):89-92

Dane J H, Topp G C (Eds) (2002) Methods of soil analysis. Soil Sci Soc Am Pre, Madison, WI

Doran J (1996) The international situation and criteria for indicators. In: Cameron KC, Comforth IS, McLaren RG, Beare MH, Basher LR, Metherell AK, Kerr LE (eds) Soil quality indicators for sustainable agriculture in New Zealand: proceedings of a workshop. Lincoln Soil Quality Research Centre, Lincoln University, Canterbury

Doran JW (2002) Soil health and global sustainability: translating science into practice. Agric Ecosyst Environ 88(2):119-127. doi:10.1016 /S0167-8809(01)00246-8

Duan L, Hao J, Xie S, Zhou Z, Ye X (2002) Determining weathering rates of soils in China. Geoderma 110(3-4):205-225. doi:10.1016 /S0016-7061(02)00231-8

Duan XW, Rong L, Zhang GL, Hu JM, Fang HY (2015) Soil productivity in the Yunnan province: spatial distribution and sustainable utilization. Soil Till Res 147:10-19. doi:10.1016/j.still.2014.11.005

Duan XW, Xie Y, Liu BY, Liu G, Feng YJ, Gao XF (2012) Soil loss tolerance in the black soil region of Northeast China. J Geo Sci 22(4):737-751. doi:10.1007/S11442-012-0959-5

Duan XW, Yun X, Feng YJ, Yin SQ (2009) Study on the method of soil productivity assessment in black soil region of Northeast China. Agr Sci China 8(4):472-481. doi:10.1016/S1671-2927(08)60234-5

Edmeades DC (2003) The long-term effects of manures and fertilisers on soil productivity and quality: a review. Nutr Cycl Agroecosystems 66(2):165-180. doi:10.1023/A:1023999816690

Edwards M J (1962) Soil erodibility factor values and soil loss tolerance. Soil loss prediction for South Carolina. Mimeo. SCS, USDA, Columbia, South Carolina, 29201

FAO/UNESCO (Food and Agriculture Organization of the United Nations/ United Nations Educational, Scientific, and Cultural Organization) (1998) Soil map of the world. Revised legend. FAO, Rome
Flach K W (1983) Soil loss tolerance. Proceedings of the natural resources modeling symposium. Pingree Park, Co. USDA, ARS, 446-448.

Francesconi W, Srinivasan R, Pérez-Miñana E, Willcock SP, Quintero M (2016) Using the soil and water assessment tool (SWAT) to model ecosystem services: a systematic review. J Hydrol 535:625-636. doi:10.1016/j.jhydrol.2016.01.034

Gantzer CJ, McCarty TR (1987) Predicting corn yield on a claypan soil using a productivity index. Trans ASABE 30(5):1347-1352. doi:10.13031/2013.30569

Guo Q, Hao Y, Liu B (2015) Rates of soil erosion in China: a study based on runoff plot data. Catena 124:68-76. doi:10.1016/j. catena.2014.08.013

Hall G F, Logan T J, Young K K (1985) Criteria for determining tolerable erosion rates. In: Follett R F and Stewart B A, ed. Soil erosion and crop productivity. Iris Y. Ballew.- Madison, Wis (USA), Am Soc Agro 119-132

Hancock GR, Wells T, Martinez C, Dever C (2015) Soil erosion and tolerable soil loss: insights into erosion rates for a well-managed grassland catchment. Geoderma 237-238:256-265. doi:10.1016/j. geoderma.2014.08.017

Hays O E, N Clark. Cropping system that help control erosion (1941) Bull 452 Wisc Soil Cons Comm, Soil Cons Serv and the Univ of Wisc Agr Exp Sta, Madison

Johnson LC (1987) Soil loss tolerance: fact or myth? J Soil Water Conserv 42(3): 155-160

Keesstra S, Pereira P, Novara A, Brevik EC, Azorin-Molina C, ParrasAlcántara L, Jordán A, Cerdà A (2016) Effects of soil management techniques on soil water erosion in apricot orchards. Sci Total Environ 551:357-366. doi:10.1016/j.scitotenv.2016.01.182

Kendall HW, Pimentel D (1994) Constraints on the expansion of the global food supply. Ambio 23(3):198-205 http://www.jstor. org/stable/4314199

Kuznetsov MS, Abdulkhanova DR (2013) Soil loss tolerance in the central chernozemic region of the European part of Russia. Eurasian Soil Sci 46(7):802-809. doi:10.1134/S1064229313050074

Lal R (2001) Soil degradation by erosion. Land Degrad Dev 12(6):519 539. doi:10.1002/ldr.472

Li L, Du S, Wu L, Liu G (2009) An overview of soil loss tolerance. Catena 78(2):93-99. doi:10.1016/j.catena.2009.03.007

Liu GS (1996) Soil physics and chemistry analysis \& description of soil profiles. Standard Press of China, Beijing (in Chinese)

Liu GG, Wang XM, Wu JL, Peng SL, Dai FQ, Zhang B (2015) Mutual tolerance ecology is a key to future eco-environmental science. Front Environ Sci 4(1):1-10 http://www.ivypub.org/FES/paperinfo/22227. shtml.

Lobo D, Lozano Z, Delgado F (2005) Water erosion risk assessment and impact on productivity of a Venezuela soil. Catena 64(2-3):297306. doi:10.1016/j.catena.2005.08.011

Lombardi NF, Bertoni J (1975) Tolerância de perdas de terra para solos do Estado de São Paulo. Bol Tech Inst Agron 28:1-12

Lu R K (1998) Principle of soil-plant nutrition and fertilizer. Chemical industry press, Beijing. 46-47, 117. (in Chinese).

Mafongoya P, Rusinamhodzi L, Siziba S, Thierfelder C, Mvumi BM, Nhua B, Hove L, Chivenge P (2016) Maize productivity and profitability in conservation agriculture systems across agro-ecological regions in Zimbabwe: a review of knowledge and practice. Agric Ecosyst Environ 220:211-225. doi:10.1016/j.agee.2016.01.017

Mandal D, Sharda VN (2013) Appraisal of soil erosion risk in the Eastern Himalayan region of India for soil conservation planning. Land Degrad Dev 24(5):430-437. doi:10.1002/ldr.1139

Mannering J V (1981) Use of soil loss tolerances as a strategy for soil conservation/soil conservation problems and prospects:[proceedings of Conservation 80, the International Conference on Soil Conservation, held at the National College of Agricultural Engineering, Silsoe, Bedford, UK, 21st-25th July, 1980]/edited by RPC Morgan. Chichester [England, Wiley, c1981. 
McCormack D E, Young K K, Kimberlin L W (1982) Current criteria for determining soil loss tolerance. In: Determinants of soil loss tolerance. ASA Special Publication No. 45, Am Soc Agr, Madison, Wisconsin. 95-112

Miao QL, Xiao W (1995) The basic precipitation features of Yunnan Province in recent 40 years. J Meteorol Sci 3:293-299 (in Chinese)

Ministry of Water Resources of the People's Republic of China (1997) Standards of the classification of soil erosion in China. China Water Power Press, Beijing (in Chinese)

Montgomery DR (2007) Soil erosion and agricultural sustainability. P Nati A Sci 104(33):13268-13272. doi:10.1073/pnas.0611508104

Morgan RPC (1987) Sensitivity of European soils to ultimate physical degradation. In: Barth H, L'Hermitage P (eds) Scientific basis for soil protection in the European community. Elsevier Applied Science, Amsterdam, pp. 147-157

Montgomery MK, Payton RW (1999) Modification of the productivity index model. Soil Till Res 52(1):11-19. doi:10.1016/S0167-1987 (99)00022-7

Myers D B, Kitchen N R, Sudduth K A (2000) Estimation of a soil productivity index on claypan soils using soil electrical conductivity. Proceedings of the 5th International Conference on Precision Agriculture, Bloomington, Minnesota, USA

National Soil Survey Office of Yunnan Province (1996) Soils of Yunnan. Yunnan Science and Technology Press, Kunming, China (in Chinese).

Nowak PJ, Timmons J, Carlson J, Miles R (1985) Economic and social perspectives on $\mathrm{T}$ values relative to soil erosion and crop productivity. Soil Erosion Crop Produc:119-132

Ongley ED, Xiaolan Z, Tao Y (2010) Current status of agricultural and rural non-point source pollution assessment in China. Environ Pollut 158(5):1159-1168. doi:10.1016/j.envpol.2009.10.047

Pacheco FAL, Varandas SGP, Sanches Fernandes LF, Valle Junior RF (2014) Soil losses in rural watersheds with environmental land use conflicts. Sci Total Environ 485-486C:110-120. doi:10.1016/j. scitotenv.2014.03.069

Paschall A H, Klingebiel A A, Allaway W H (1956) Committee report: permissible soil loss and relative erodibility of different soils. Agr Res Serv and Soil Cons Serv, Washington DC

Pierce FJ, Larson WE, Dowdy RH, Graham WAP (1983) Productivity of soil: assessing of long-term changes due to erosion. J Soil Water Conserv 38(1):39-44

Pimentel D (2006) Soil erosion: a food and environmental threat. Environ Dev Sustain 8(1):119-137. doi:10.1007/s10668-005-1262-8

Pretorius JR, Cooks J (1989) Soil loss tolerance limits: an environmental management tool. GeoJournal 19(1):67-75. doi:10.1007/BF00620551

Quynh LTP, Billen G, Garnier J, Théry S, Fézard C (2005) Nutrient (N, P) budgets for the Red River basin (Vietnam and China). Global Biogeochem Cy 19(2). doi:10.1029/2004GB002405

Renard K G, Foster G R, Weeies G A, McCool D (1997) Predicting soil erosion by water. A guide to conservation planning with the revised universal soil loss equation (RUSLE). USDA. Agric Handb. No. 703. US Gov Print. Office, Washington, DC. 150.

Renschler CS, Harbor J (2002) Soil erosion assessment tools from point to regional scales - the role of geomorphologists in land management research and implementation. Geomorphology 47(2):189209. doi:10.1016/S0169-555X(02)00082-X

Research group and cooperative research group on Chinese soil taxonomy (RGCRG) (1995) Index on Chinese soil taxonomy (2nd version). Chinese Agriculture Science and Technology Press, Beijing, pp. 1-218 (in Chinese)

Rijsberman FR, Wolman MG (1985) Effect of erosion on soil productivity: an international comparison. J Soil Water Conserv 40(4):349-354

Rittall W F, Swader F N (1979) Soil loss limits and water quality. Paper presented at a symposium on determinants of soil loss tolerance. Soil Sci Soc Amer. Ann Mtg, Fort Collins, Co, August 1979
Runge CF, Larson WE, Roloff G (1986) Using productivity measures to target conservation programs: a comparative analysis. J Soil Water Conserv 41(1):45-49

Sanchez PA (2002) Soil fertility and hunger in Africa. Science 295(5562): 2019-2020. doi:10.1126/science.1065256

Schertz DL (1983) The basis for soil loss tolerances. J Soil Water Conserv 38:10-14

Schertz D L, Mark A N (2006) Erosion tolerance/ soil loss tolerance. In: Rattan Lal. Encyclopedia of soil science (2an ed). Boca Raton, FL: Taylor \& Francis, 640-642.

Schwab G O, Fangmeier D D, Elliot W J(1993) Soil and water conservation engineering. John Wiley \& Sons, Inc

Shtomrel YA, Lisetskii FN, Sukhanovskii YP, Srtelnikova AV (1998) Soil loss tolerance of brown forest soils of Northwestern Caucasus under intensive agriculture. Eurasian Soil Sci 31(2):200-206 http://dspace. bsu.edu.ru/handle/123456789/2083.

Simonneaux V, Cheggour A, Deschamps C, Mouillot F, Cerdan O, Bissonnais Y (2015) Land use and climate change effects on soil erosion in a semi-arid mountainous watershed (High Atlas, Morocco). J Arid Environ1 22:64-75. doi:10.1016/j.jaridenv.2015.06.002

Skidmore E L (1982) Soil loss tolerance. In: Determinants of soil loss tolerance. ASA Special Publication No. 45, Am Soc Agr, Madison, Wisconsin, p 87-94

Smith RM, Stamey WL (1965) Determining the range of tolerable erosion. Soil Sci 100(6):414-424

Soil Science Society of America (2008) Glossary of soil science terms. ASA-CSSA-SSSA

Sparovek G, Schnug E (2001) Temporal erosion-induced soil degradation and yield loss. Soil Sci Soc Am J 65(5):1479-1486. doi:10.2136/sssaj2001.6551479x

Sparovek G, Weill MM, Ranieiri SBL, Schnug E, Silva EF (1997) The life-time concept as a tool for erosion tolerance definition. Sci Agr 54(SPE):130-135. doi:10.1590/S0103-90161997000300015

Stavi I, Bel G, Zaady E (2016) Soil functions and ecosystem services in conventional, conservation, and integrated agricultural systems. A review Agron Sustain Dev 36(2):1-12. doi:10.1007/s13593-016-0368-8

Stocking MA (1984) Erosion and soil productivity: a review. Food and agriculture organization consultant' working paper no. 1, soil conservation programme, land and water development division. Food and Agriculture organization, Rome, Italy

Teasdale JR, Coffman CB, Mangum RW (2007) Potential long-term benefits of no-tillage and organic cropping systems for grain production and soil improvement. Agron J 99(5):1297-1305. doi:10.2134/agronj2006.0362

Tenberg A, Da Veiga M, Dechen SCF, Stocking MA (2014) Modelling the impact of erosion on soil productivity: a comparative evaluation of approaches on data from southern Brazil. Exp Agr 34(01):55-71. doi:10.1017/S0014479798001033

The National Soil Survey Office (1995) Chinese soil genus records, vol 5. China Agriculture Press, Beijing (in Chinese)

Thompson AL, Gantzer CJ, Hammer RD (1992) Productivity of a claypan soil under rain-fed and irrigated conditions. J Soil Water Conserv 47(5):405-410

U S Department of Agriculture Natural Resources Conservation Service (USDA-NRCS) (1999) National soil survey handbook: title 430-VI. US Government printing office, Washington DC

Udawatta RP, Henderson GS (2003) Root distribution relationships to soil properties in Missouri Oak stands: a productivity index approach. Soil Sci Soc Am J 67(6):1869-1878. doi:10.2136/sssaj2003.1869

Valera CA, Valle Junior RF, Varandas SGP, Sanches Fernandes LF, Pacheco FAL (2016) The role of environmental land use conflicts in soil fertility: a study on the Uberaba River basin, Brazil. Sci Total Environ 562:463-473. doi:10.1016/j.scitotenv.2016.04.046

Valle Junior RF, Varandas SGP, Sanches Fernandes LF, Pacheco FAL (2014) Environmental land use conflicts: a threat to soil 
conservation. Land Use Policy 41:172-185. doi:10.1016/j. landusepol.2014.05.012

Van Oost K, Quine TA, Govers G, Gryze SD, Six J, Harden JW, Ritchie JC, McCarty GW, Heckrath G, Kosmas C, Giraldez JV, Marques da Silva JR, Merckx R (2007) The impact of agricultural soil erosion on the global carbon cycle. Science 318(5850):626-629. doi:10.1126/science.1145724

Verheijen FGA, Jones RJA, Rickson RJ, Smith CJ (2009) Tolerable versus actual soil erosion rates in Europe. Earth Sci Rev 94(1):23-38. doi:10.1016/j.earscirev.2009.02.003

Wang GL, Zhang GZ (1983) Soil knowledge and general detailed of soil survey technology. Water and Electric Power Press, Beijing (in Chinese)

Wan JG, Yang LZ, Shan YH (2001) Application of fuzzy mathematics to soil quality assessment. Acta Pedol Sin 38:176-183 (in Chinese)

Whiffin VS, Van Paassen LA, Harkes MP (2007) Microbial carbonate precipitation as a soil improvement technique. Geomicrobiol J 24(5):417-423. doi:10.1080/01490450701436505

Wilhelm WW, Johnson JMF, Hatfield JL, Voorhees WB, Linden DR (2004) Crop and soil productivity response to corn residue removal. Agron Jo 96(1):1-17. doi:10.2134/agronj2004.1000
Wilson JP, Sandor SP, Nielsen GA (1991) Productivity index model modified to estimate variability of Montana small yields. Soil Sci Soc Amer 55(1):228-234

Wischmeier WH, Smith DD (1979) Predicting rainfall erosion losses from cropland east of the Rocky Mountains. Agric Handbook. No 282. USDA, Washington, DC

Yang J, Hammer RD, Thompson AL, Blancha RW (2003) Predicting soybean yield in a dry and wet year using a soil productivity index. Plant Soil 250(2):175-182. doi:10.1023 /A:1022801322245

Young KK (1980) Impact of erosion on soils for United States. In: Deboodt M, Grabriels D (eds) Assessment of erosion. John Wiley and Sons, New York

Zhang WL, Wu SX, Ji HJ, Kolbe H (2004) Estimation of agricultural non-point source pollution in China and the alleviating strategies I. Estimation of agricultural non-point source pollution in China in early 21 century. Sci Agr Sinica 37(7):1008-1017 